\title{
Comparison of temporal trends from multiple soil moisture data sets and precipitation: The implication of irrigation on regional soil moisture trend
}

\author{
Jianxiu Qiu ${ }^{\mathrm{a}, *}$, Quanzhou Gao ${ }^{\mathrm{a}}$, Sheng Wang ${ }^{\mathrm{b}}$, Zhenrong Su $^{\mathrm{a}}$ \\ a Guangdong Provincial Key Laboratory of Urbanization and Geo-simulation, School of Geography and Planning, Sun Yat-sen University, Guangzhou \\ 510275, China \\ ${ }^{\mathrm{b}}$ Key Laboratory of Water Cycle and Related Land Surface Processes, Institute of Geographic Sciences and Natural Resources Research, Chinese Academy of \\ Sciences, Beijing 100101, China
}

\section{A R T I C L E I N F O}

\section{Article history:}

Received 31 March 2015

Received in revised form 8 November 2015

Accepted 17 November 2015

Available online 11 December 2015

\section{Keywords:}

Surface soil moisture

Trend analysis

Multi-satellite remote sensing

ERA-Interim/Land reanalysis

Huang-Huai-Hai Plain

Irrigation effect

\begin{abstract}
A B S T R A C T
In this study, soil moisture trend during 1996-2010 in China was analyzed based on three soil moisture data sets, namely microwave-based multi-satellite surface soil moisture product released from European Space Agency's Climate Change Initiative (ESA CCI), ERA-Interim/Land reanalysis, and in-situ measurements collected from the nationwide agro-meteorological network. Taking the in-situ soil moisture as reference, it is found that ESA CCI generally captured soil moisture trend more accurately than ERA-Interim/Land did. From the spatial distribution of trend analysis results, it is seen that significant decreasing trend for summer soil moisture in northwestern China and northern Inner Mongolia, as well as the significant increasing trend for autumn soil moisture in northern China were identified by both ESA CCI and ERA-Interim/Land. This is in alignment with results from gauge-based precipitation provided by Institute of Geographic Sciences and Natural Resources Research (IGSNRR) and satellite-based precipitation from Tropical Rainfall Measuring Mission (TRMM). However, disagreements in derived trends between ESA CCI, ERA-Interim/Land and IGSNRR were observed in the southwest and north of China, especially in major irrigation regions, such as the oases in northern Xinjiang and large areas in Sichuan province. Prominent difference between soil moisture and precipitation exhibited in the extensively irrigated Huang-Huai-Hai Plain. The spatial coincidence between significantly wetting areas (identified by ESA CCI) and heavily irrigated areas, as well as the grid-based Student's $t$-test sampling from various irrigation levels revealed that the observed discrepancy was caused by massive anthropogenic interference in this region. Results indicate that, for regions with great magnitude of human interference, modules considering actual irrigation practice are crucial for successful modeling of soil moisture and capturing the long-term trend. Furthermore, results could provide insights on hindcast of historical irrigation areas using satellite-based precipitation and soil moisture data sets.
\end{abstract}

(c) 2015 Elsevier B.V. All rights reserved.

\section{Introduction}

Soil moisture is a crucial driver in water and energy exchange between land surface and atmosphere, as it controls the partitioning of precipitation between runoff and infiltration, the partitioning of incoming radiation between latent and sensible heat fluxes. Information on soil moisture is valuable in many disciplines includ-

\footnotetext{
* Corresponding author at: Guangdong Provincial Key Laboratory of Urbanization and Geo-simulation, School of Geography and Planning, Sun Yat-sen University, No. 135, Xingang Xi Road, Guangzhou, 510275, China. Fax: +86 02084112593.

E-mail address: qiujianxiu@mail.sysu.edu.cn (J. Qiu).
}

ing agronomy and environmental sciences, e.g., in application of vegetation growth/restoration in semiarid environments (Ahmad et al., 2010), soil erosion rate prediction (Wei et al., 2007) and crop yield estimation (Green and Erskine, 2004; Jaynes et al., 2003). Considering its importance in earth science, soil moisture is recognized as an Essential Climate Variable (GCOS, 2010), and the knowledge of its temporal trend and variability is of essential importance for understanding the effect of climate change on hydrological processes.

Long-term observations of soil moisture are valuable for investigating the trend and dynamics of soil moisture and the severity and duration of drought events. Nevertheless, due to the limited spatial and temporal coverage of ground-based observation networks in 
China, such investigations heavily relied on indirect measurements such as precipitation and air temperature (Wang et al., 2003; Xin et al., 2006; Zhai et al., 2010) and on soil moisture simulations from land surface models (Ma and Fu, 2006; Wang et al., 2011; Zou et al., 2005; Zuo and Zhang, 2007). However, the accuracy of model-based soil moisture is constrained by the quality of model forcing and the large horizontal/vertical heterogeneity of soil properties that are not readily observable (Hain et al., 2011). In addition, it has been proved that influences from anthropogenic activities, such as excessive groundwater-fed irrigation and large-scale water diversion projects will result in significant change in surface soil moisture by altering the sensible and latent heat flux (Chen and Xie, 2010; Zou et al., 2014). Nonetheless, the majority of land surface models lack the consideration of irrigation effect on water redistribution in the terrestrial system, and simulate surface soil moisture without incorporating irrigation module (Drewniak et al., 2013). All these factors have given rise to considerable uncertainties in soil moisture simulated by land surface models in the intensively irrigated region.

Recently, initiated within the Water Cycle Multi-mission Observation Strategy (WACMOS) project, the latest version of soil moisture product (ESA CCI) merging active and passive microwave observations was released to public domain. Through minimizing the effects of differences in sensor specifications, particularly in microwave frequency and spatial resolution, the ESA CCI product provides relatively consistent and reliable information of soil moisture worldwide. At the global scale, this ESA CCI data set has been extensively validated against in-situ network observations and various land surface model simulations (Albergel et al., 2013a,b; Dorigo et al., 2012, 2015; Liu et al., 2012). In addition, the ESA CCI data set covers the period of 1979-2013, longer than any individual microwave soil moisture product, serving as an independent data set from land surface model for studying multi-decadal behavior of soil moisture.

Previous studies on the topics of long-term soil moisture trend and dynamics were mostly conducted on global scales, and there appeared to be a lack of detailed discussion on the inconsistency in trends derived from different soil moisture products. Moreover, most research on soil moisture temporal trend drew their conclusions solely based on land surface models without the consideration of increasingly intensified human interference. In this study, we exploit the readily available soil moisture data set from ESA CCI product, along with ERA-Interim/Land reanalysis and agrometeorological network observations to examine the long-term soil moisture trend over China. Detailed comparative study is conducted on the performance of three soil moisture data sets in capturing the temporal trend. Following this, the discrepancies in the spatial patterns of trends between precipitation, ground-based, satellite-based, and model-based soil moisture are analyzed, and the underlying factors are discussed in detail, with the main focus on possible human interference impact on long-term soil moisture trend.

\section{Materials and methodology}

\subsection{Soil moisture data sets}

\subsubsection{ESA CCI product}

The ESA CCI product was supported under the framework of European Space Agency's Water Cycle Multi-mission Observation Strategy (WACMOS) project and Climate Change Initiative (http://www.esa-soilmoisture-cci.org). The ESA CCI data set was derived from passive products including observations from Scanning Multichannel Microwave Radiometer (SMMR), Special Sensor Microwave Imager (SSM/I), Tropical Rainfall Measuring Mission
Microwave Imager (TMI), Advanced Microwave Scanning Radiometer for the Earth Observing System (AMSR-E), Advanced Microwave Scanning Radiometer-2 (AMSR2), and WindSat; and active products including the Advanced Scatterometer (ASCAT) observations and scatterometer observations on board the European Remote Sensing (ERS) satellite (Liu et al., 2011, 2012; Wagner et al., 2012). The ESA CCI data set provides surface soil moisture information in volumetric unit $\left(\mathrm{m}^{3} \mathrm{~m}^{-3}\right)$ on a daily basis with a spatial resolution of $0.25^{\circ}$. Apart from the difference in quality of individual data source, uncertainties of ESA CCI product could also result from the selected merging procedure for combining retrievals from different observation systems, different mission designs as well as different retrieval algorithms. Despite some limitations, the ESA CCI product has demonstrated great potential for evaluating model performance (Albergel et al., 2013a,b; Dorigo et al., 2012, 2015; Loew et al., 2013), and for studying the global-scale land-atmosphere interaction (Hirschi et al., 2014). In this study, the latest version (v02.1) of ESA CCI was used for long-term trend analysis.

\subsubsection{ERA-Interim/Land reanalysis}

ERA-Interim/Land is a newly released global land surface reanalysis data set covering the period 1979-2010. It was produced with the latest version of the Hydrology Tiled ECMWF Scheme for Surface Exchanges over Land (HTESSEL) model using atmospheric forcing from ERA-Interim, with precipitation adjustments based on Global Precipitation Climatology Project (GPCP) v2.1. There are several improvements of land surface parameterization scheme in ERAInterim/Land compared to ERA-Interim (Balsamo et al., 2015). Four layers of soil $(0-7,7-28,28-100$, and $100-289 \mathrm{~cm})$ are considered in ERA-Interim/Land reanalysis, and soil moisture is provided at 00:00, 06:00, 12:00 and 18:00 UTC with the unit of $\mathrm{m}^{3} \mathrm{~m}^{-3}$ (Albergel et al., 2013a,b). All of the 6-h soil moisture data were used in the analysis to construct the daily average time series. In order to be comparable with the sensing depth of the satellite sensors, only the first layer $(0-7 \mathrm{~cm})$ of reanalysis data were used in the study.

\subsubsection{In-situ network observations}

In-situ soil moisture measurements were collected from nationwide agro-meteorological network (http://data.cma.gov.cn/data/ detail/dataCode/AGME_AB2_CHN_TEN.html), and provided by the National Meteorological Information Center of the China Meteorological Administration (CMA). The location and distribution of the stations are shown in Fig. 1. In order to monitor the soil water status in the cropland, measurements were taken on the 8th, 18th and 28th of each month since 1991. At each agro-meteorological station, soil moisture was measured at the depths of $10 \mathrm{~cm}, 20 \mathrm{~cm}$, $30 \mathrm{~cm}, 50 \mathrm{~cm}, 70 \mathrm{~cm}$ and $100 \mathrm{~cm}$. No measurements were recorded under frozen soil condition. This data set of in-situ soil moisture measurements from nationwide agro-meteorological network has been widely used for investigating soil moisture spatial and temporal characteristics and validation of microwave soil moisture over China (Qiu et al., 2013; Yuan et al., 2015). Similar to ERAInterim/Land reanalysis, only the first layer $(10 \mathrm{~cm})$ of in-situ soil moisture observations were used in the study. As soil moisture was measured by gravimetric method and recorded as a relative ratio to the field capacity, the global porosity map provided along with the ESA CCI v02.1 product was used to convert them to volumetric unit. Since the absolute magnitude of measurements will not affect trend detection, we adopted a fixed field capacity/porosity ratio during the conversion.

\subsection{Precipitation data sets}

The precipitation data set used in this study was established by Zhang et al. (2014) from the Institute of Geographic Sciences and Natural Resources Research (IGSNRR). The IGSNRR data set 


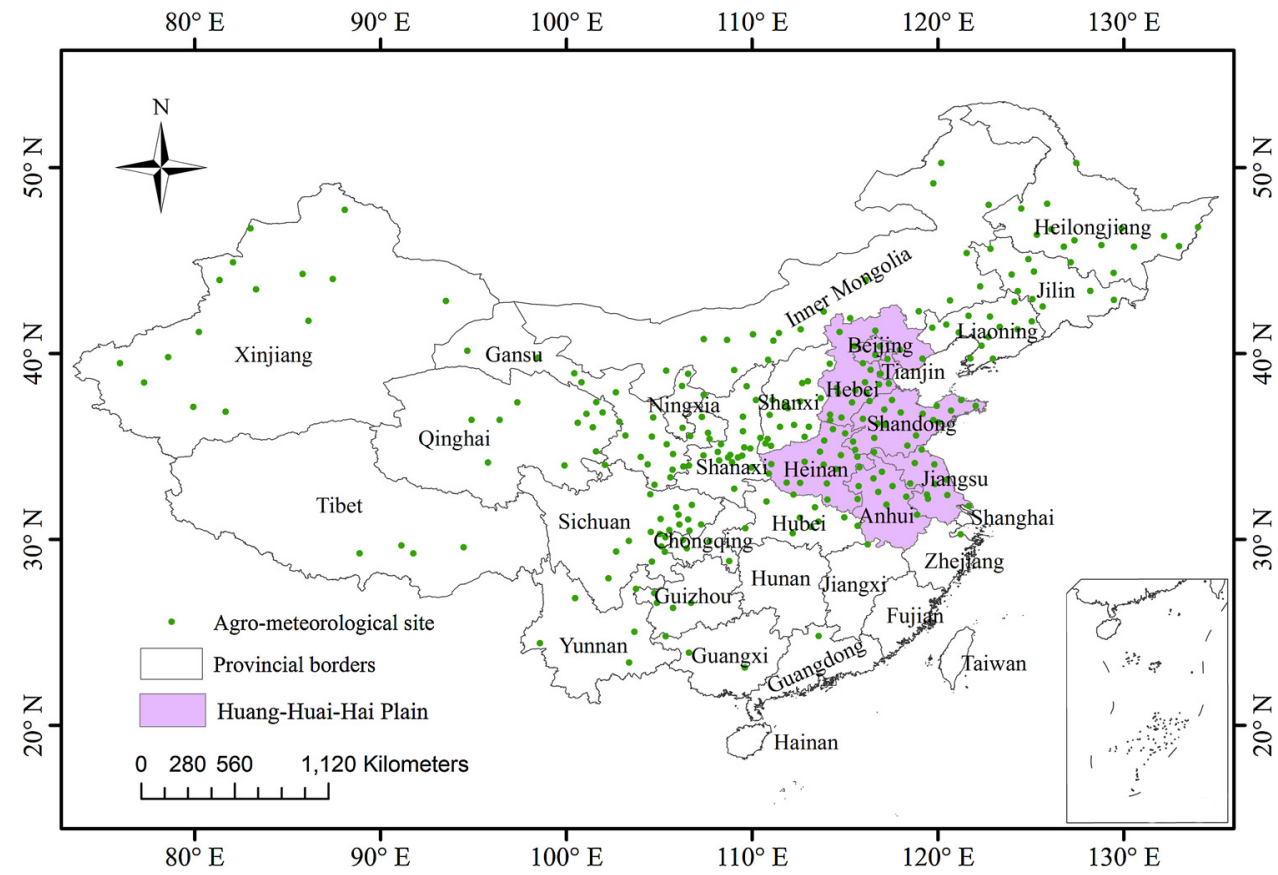

Fig. 1. Spatial distribution of agro-meteorological sites in China.

spatially covered the entire China with $0.25^{\circ}$ grid from 1952 to 2012. The data set was interpolated based on the daily precipitation observations from 756 CMA meteorological stations, using the synergraphic mapping system algorithm proposed by Shepard (1984). In addition, the IGSNRR data set was adjusted with 12 monthly scaling factors for each grid cell, so that the monthly mean of product matched that of the CMA observations during the period of 1962-2002 (Maurer et al., 2002; Tang et al., 2009). For detailed information on this data set, please refer to Zhang et al. (2014).

The second precipitation data set used in this study was the Tropical Rainfall Measuring Mission (TRMM) multi-satellite precipitation analysis (3B43V7) provided by NASA Goddard Space Flight Center (Huffman et al., 2007). The TRMM data set combined the 3-h merged high-quality microwave/infrared estimates with the monthly accumulated rain gauge analysis from Global Precipitation Climatology Centre (GPCC). The spatial coverage of TRMM data set extended from $50^{\circ}$ south to $50^{\circ}$ north latitude and was available from 1998 with monthly temporal resolution and $0.25^{\circ}$ spatial resolution. The processing algorithms of TRMM 3B43 included two steps, firstly, the 3-h merged estimates were summed for the calendar month, and then the rain gauge data were applied to this multi-satellite estimates for bias adjustment. This bias adjustment algorithm was similar to that of the GPCP's monthly satellite-gauge product (Adler et al., 2003; Huffman et al., 1997). For detailed information on this product, please refer to Huffman et al. (2010).

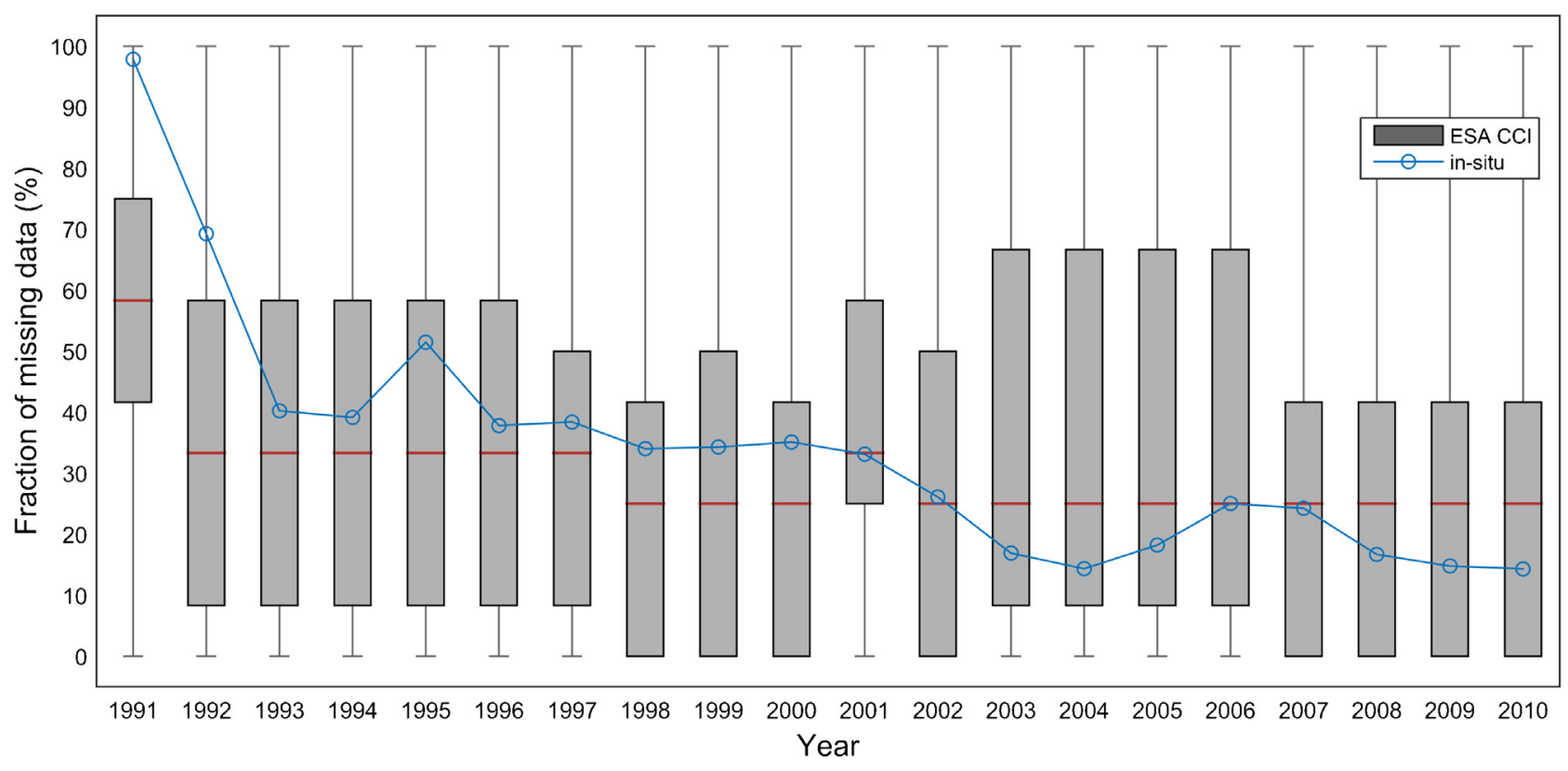

Fig. 2. Fractions of missing data on the monthly times series from ESA CCI and in-situ observations during 1991-2010. 


\subsection{Trend analysis methods}

Before trend analysis, daily values of ESA CCI, ERA-Interim/Land and in-situ measurements at 10-day intervals were converted to monthly time series, and then averaged for each season: December-February (DJF), March-May (MAM), June-August (JJA), and September-November (SON). The same processing was applied to daily IGSNRR precipitation and monthly TRMM data to construct seasonal time series. In constructing the time series of annual mean for trend analysis, the conditions with snow cover were filtered following Dorigo et al. (2012) and Albergel et al. (2013b). Two nonparametric methods, namely Mann-Kendall test and Spearman's Rho test were employed to test the significance of trend in time series. These two robust methods do not require normality or linearity, and are less sensitive to outliers.

\subsubsection{Mann-Kendall test}

To test the significance of trend using Mann-Kendall (MK) method, the first step is to construct the MK statistic $S$ and its variance, denoted as $\operatorname{var}(S)$ (Hirsch et al., 1982; Kendall, 1975; Khaliq et al., 2009; Mann, 1945; Renard et al., 2008). The standardized statistics $Z$ is then calculated using $S$ and $\operatorname{var}(S)$ in Eq. (1):

$Z=\left\{\begin{array}{cc}\frac{S-1}{\sqrt{\operatorname{var}(S)}} & \text { if } S>0 \\ 0 & \text { if } S=0 \\ \frac{S+1}{\sqrt{\operatorname{var}(S)}} & \text { if } S<0\end{array}\right.$

The statistics $Z$ is utilized to test the presence of a statistically significant trend by comparison with tolerable probability. In this study, the default significance level is set as 0.05 unless otherwise stated as in Section 4.1. In addition, the change rates (change magnitude) of soil moisture and precipitation are evaluated using the Sen's slope (Sen, 1968):

$b_{\text {Sen }}=\operatorname{Median}\left(\frac{\mathrm{SM}_{i}-\mathrm{SM}_{j}}{i-j}\right) \forall j<i$

if there are $m$ values in the time series then one can get as many as $n=m(m-1) / 2$ slope estimates and $b_{\text {Sen }}$ is taken as the median of these $n$ values.

\subsubsection{Spearman's Rho test}

This test is based on the Spearman's rank correlation coefficient $r_{\mathrm{SRC}}$, which is defined as (Dahmen and Hall, 1990):

$r_{\mathrm{SRC}}=1-\frac{6 \sum_{i=1}^{m} d_{i}^{2}}{m\left(m^{2}-1\right)}$

where $m$ is the observation number or simulation length at a given grid cell, $d_{i}$ is the rank of $i$ th observation or simulation $S M_{i}$ in the time series. If there are ties, the convention is to take the average rank. The null hypothesis is tested by calculating the test statistic $t_{\mathrm{SRC}}$ :

$t_{\mathrm{SRC}}=r_{\mathrm{SRC}}\left(\frac{m-2}{1-r_{\mathrm{SRC}}^{2}}\right)^{0.5}$

where $t_{\mathrm{SRC}}$ has Student's $t$-distribution with $v=m-2$ degrees of freedom. At $a$ significance level, the time series has no trend if $t_{v, \alpha / 2}<t_{\mathrm{SRC}}<t_{v, 1-\alpha / 2}$.

\section{Results}

\subsection{Data gaps of multiple soil moisture data sets}

Since it is confirmed that data gaps have strong effect on the performance of ESA CCI (Dorigo et al., 2014; Loew et al., 2013), and on the results of trend analysis (Khaliq et al., 2009; Renard et al., 2008), it is natural to seek coincident temporal coverage of these data sets with minimum data gaps. Fractions of missing data on monthly time series from both ESA CCI and in-situ observations over China are shown in Fig. 2. The selection of study period was based on the following reasons. Firstly, the observation density of ESA CCI increased when both active and passive microwave products were used synergistically since July 1991 (Dorigo et al., 2015). As for insitu observations from agro-meteorological network, the data gap was most obvious in the first few years, i.e., during 1991-1995. It was not until 1996 that the missing data fraction decreased below $50 \%$ (Fig. 2). In addition, the latest version of ERA Interim/Land provides soil moisture reanalysis till the end of 2010. Based on these factors, we selected $1996-2010$ as the study period.

\subsection{Trends detected from multiple soil moisture data sets}

Both satellite-based and model-based soil moisture data sets were firstly validated against in-situ observations from agrometeorological sites using Spearman's rank correlation $\left(r_{\mathrm{SRC}}\right)$. Results showed that the median $r_{\mathrm{SRC}}$ between monthly in-situ observations and ESA CCI was 0.40 , which was comparable to the global-scale evaluation result of 0.46 (Dorigo et al., 2015), and the estimated median $r_{\mathrm{SRC}}$ was 0.54 for ERA Interim/Land.

After validation against in-situ measurements, the seasonal trend analysis results from different soil moisture products were also compared to those from in-situ observations and summarized in Table 1 . The numbers of in-situ sites identified with significant trends $(p<0.05)$ by MK and Spearman's Rho tests are shown in the parentheses, and the ratios of sites collocated with grid cells from ESA CCI and ERA Interim/Land which detected the same level of significant trends are shown as percentage. There are several points worth noting from Table 1. Firstly, it is seen that the results from both MK and Spearman tests were similar, especially for annual mean time series, which increased the credibility of the analysis results. However, the discrepancy between two methods in detecting significantly increasing trend was larger than that in detecting significantly decreasing trend. This is attributed to the different handling of tie values in the employed two methods. As tie values commonly occurred after irrigation when surface soil moisture was up to field capacity, there was noticeable discrepancy between MK and Spearman methods in detecting significantly increasing trend at agro-meteorological sites. Secondly, the agreement between ESA CCI and in-situ observations was generally better than that between ERA-Interim/Land and in-situ observations. The ratio that both ESA CCI and in-situ observations identified significantly increasing (decreasing) trend was about 30\% (34-39\%), whereas the ratio that ERA-Interim/Land detected consistent significantly increasing (decreasing) trend was 24\% (19-23\%). In addition, taking the insitu observations as benchmark, the ERA Interim/Land had better accuracy in identifying the significantly increasing trend than in the identification of decreasing trend.

It is worth mentioning that, under the current comparative framework, there is difference in spatial representative between in-situ observations and remotely sensed (or reanalysis) soil moisture. To circumvent this issue, we also examined the consistency of trends derived from soil moisture data sets with the same $0.25^{\circ}$ spatial resolution. The grid-based intercomparison results from the annual mean of ESA CCI and ERA-Interim/Land are shown in analogy to confusion matrix in Fig. 3. Four classes namely significantly 
Table 1

Seasonal trend analysis results from ESA CCI and ERA Interim/Land compared to those from in-situ observations.

\begin{tabular}{|c|c|c|c|c|c|c|c|c|c|}
\hline & & \multicolumn{2}{|l|}{ Spring } & \multicolumn{2}{|l|}{ Summer } & \multicolumn{2}{|l|}{ Autumn } & \multicolumn{2}{|l|}{ Annual } \\
\hline & & MK & Spearman & MK & Spearman & MK & Spearman & MK & Spearman \\
\hline \multirow[t]{2}{*}{ ESA CCI } & Significantly increasing & $24.2 \%(33)$ & $30.8 \%(39)$ & $27.6 \%(29)$ & $29.7 \%(37)$ & $31.6 \%(19)$ & $32.0 \%(25)$ & $29.8 \%(57)$ & $30.5 \%(59)$ \\
\hline & Significantly decreasing & $17.4 \%(23)$ & $24.0 \%(25)$ & $40.0 \%(15)$ & $50.0 \%(14)$ & $7.7 \%(13)$ & $7.7 \%(13)$ & $38.7 \%(31)$ & $34.3 \%(35)$ \\
\hline \multirow[t]{2}{*}{ ERA Interim/Land } & Significantly increasing & $21.2 \%$ & $15.4 \%$ & $3.5 \%$ & $8.1 \%$ & $10.5 \%$ & $12.0 \%$ & $24.6 \%$ & $23.7 \%$ \\
\hline & Significantly decreasing & $4.4 \%$ & $12.0 \%$ & $13.3 \%$ & $14.3 \%$ & $0.0 \%$ & $7.7 \%$ & $19.4 \%$ & $22.9 \%$ \\
\hline
\end{tabular}

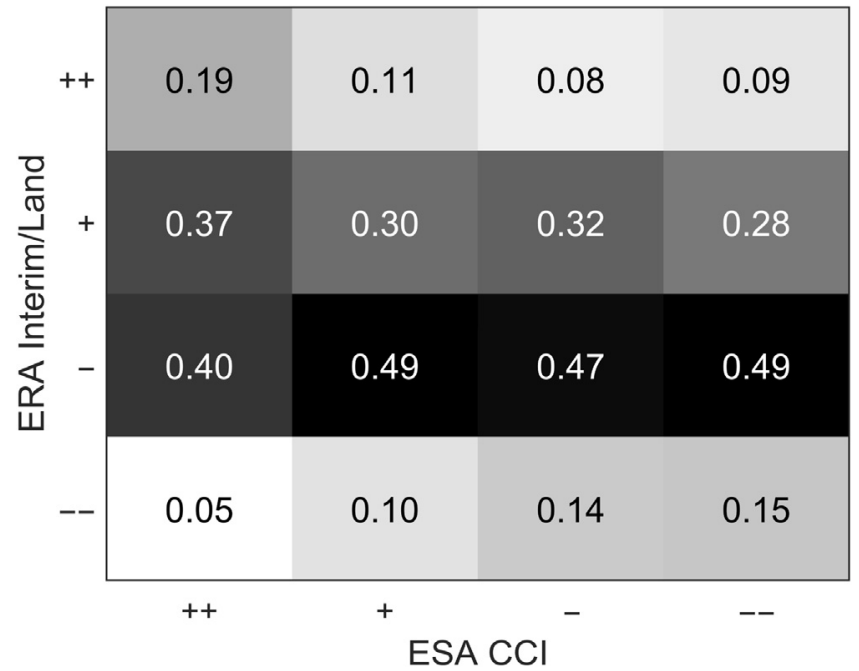

Fig. 3. Comparison between ESA CCI and ERA Interim/Land in identifying four types of soil moisture trends: significantly increase $(p<0.05)$, increase $(p>=0.05)$, decrease $(p>=0.05)$, and significantly decrease $(p<0.05)$. Four classes are denoted as “++", “+", “-” and “--" respectively.

increasing ( $p<0.05)$, increasing $(p>=0.05)$, decreasing $(p>=0.05)$, significantly decreasing $(p<0.05)$ are denoted as “++", “+”, “-” and "- - " respectively, and data set on the horizontal axis is regarded as reference, as "ground truth" is not included here. It is seen from Fig. 3 that there was obvious discrepancy between ESA CCI and ERA Interim/Land in detected increasing trends. The agreement rates between two data sets in indentifying the significantly increasing $(++)$ and increasing $(+)$ trends were $19 \%$ and $30 \%$ respectively. Taking ESA CCI as benchmark, $40 \%$ areas with significantly increasing $(++)$ trend were identified as decreasing $(-)$ by ERA Interim/Land.

Spatial consistency in detected trends between in-situ observations and two soil moisture products (ESA CCI and ERAInterim/Land) are shown in Fig. 4. Color shading indicates the magnitude of changing rates $\left(\mathrm{m}^{3} \mathrm{~m}^{-3} \mathrm{yr}^{-1}\right)$ from all data sets. For ESA CCI and ERA-Interim/Land, grid cells with increasing (decreasing) trend significant at 0.05 level are outlined by blue (red) solid lines. For in-situ measurements, sites with increasing (decreasing) trend significant at 0.05 level are marked by triangles with blue (red) edges. Consistent and significant drying trend of summer soil moisture in Inner Mongolia of north China and in northwestern China, and significant increasing trend in the eastern Tibetan Plateau during summer can be seen in all three data sets. Besides, the wetting trend of soil moisture during autumn in northern China was also identified as significant by both ESA CCI and ERAInterim/Land.

With respect to the discrepancy between ESA CCI and ERAInterim/Land, noticeable differences were observed in the major irrigation areas of China. It is noted that significant increasing trend during spring was detected by ESA CCI in Sichuan province of southwest China $\left(28-32^{\circ} \mathrm{N}, 103-108^{\circ} \mathrm{E}\right.$, one of the main grain production bases and irrigation area in China, see Fig. 6a), whereas a contrasting trend was derived from ERA-Interim/Land. Also in this area, a significant decreasing trend was identified by ERA-Interim/Land for summer and annual mean time series, while the trend was not obvious in ESA CCI. Moreover, it is interesting to note that the oases to the north rim of Tarim Basin were identified by ESA CCI to be significantly wetting during autumn when irrigation occurred, while the trend was much less obvious in ERA-Interim/Land. In addition, it is evident that both ESA CCI and in-situ soil moisture measurements detected noticeable increasing trend in the Huang-Huai-Hai Plain (a primary gain base of China, comprised of Tianjin, Beijing, and five provinces: Anhui, Hebei, Henan, Jiangsu and Shandong, see Fig. 6a) for summer, while the increasing trend was not significant in ERA-Interim/Land.

\subsection{Comparing trends of soil moisture and precipitation}

To present a comprehensive view of precipitation change, both gauge-based and satellite-based precipitation data sets (IGSNRR and TRMM) were employed to detect the precipitation trend over China. As the IGSNRR precipitation data set covered the study period of 1996-2010 while TRMM data only started from 1998, the IGSNRR and TRMM precipitation were used as primary and auxiliary data respectively for the trend analysis in this study. Spatial structure of the trend detected by MK method from IGSNRR precipitation is shown in Fig. 5, and grid cells with increasing (decreasing) trend significant at 0.05 level are outlined by solid blue (red) lines. Overall, there was a significant decreasing trend in summer precipitation in northwestern China and over southern China (to the south of the Yangtze River) with highest magnitude of about $-8 \mathrm{~mm} \mathrm{yr}^{-1}$, which was also prominent in annual mean time series. A significant increasing trend was also identified for autumn precipitation in the Tarim Basin of Xinjiang.

Compared with IGSNRR precipitation, soil moisture trend derived from ESA CCI showed a consistent decreasing trend during summer in northern Inner Mongolia. The general wetting trend was also exhibited in the southwest of Xinjiang and northern China from ESA CCI, especially during autumn (Fig. 4c), which is in alignment with the study results of Su et al., 2016. However, noticeable difference existed between trends from IGSNRR precipitation and ESA CCI. For instance, the significant drying trend during summer in southeastern China $\left(25-30^{\circ} \mathrm{N}, 110-120^{\circ} \mathrm{E}\right)$, which spatially coincides with the irrigation areas in Hunan and Jiangxi provinces (see Fig. 6a), was not reflected in ESA CCI. In addition, the ESA CCI showed statistically significant increasing trend in the Huang-HuaiHai Plain, especially in summer when precipitation increase was not significant.

The spatial similarity in trends between ERA-Interim/Land reanalysis and IGSNRR was generally higher than that between ESA CCI and IGSNRR. Specifically, ERA-Interim/Land showed a consistent and significant drying trend to the south of the Yangtze River and in northern China during summer. In addition, both ERAInterim/Land and IGSNRR identified similar spatial extent in the eastern Tibetan Plateau to be significantly drying during autumn. However, different from IGSNRR, ERA-Interim/Land identified considerably larger areas of China to be significantly drying from trend analysis of annual mean. 

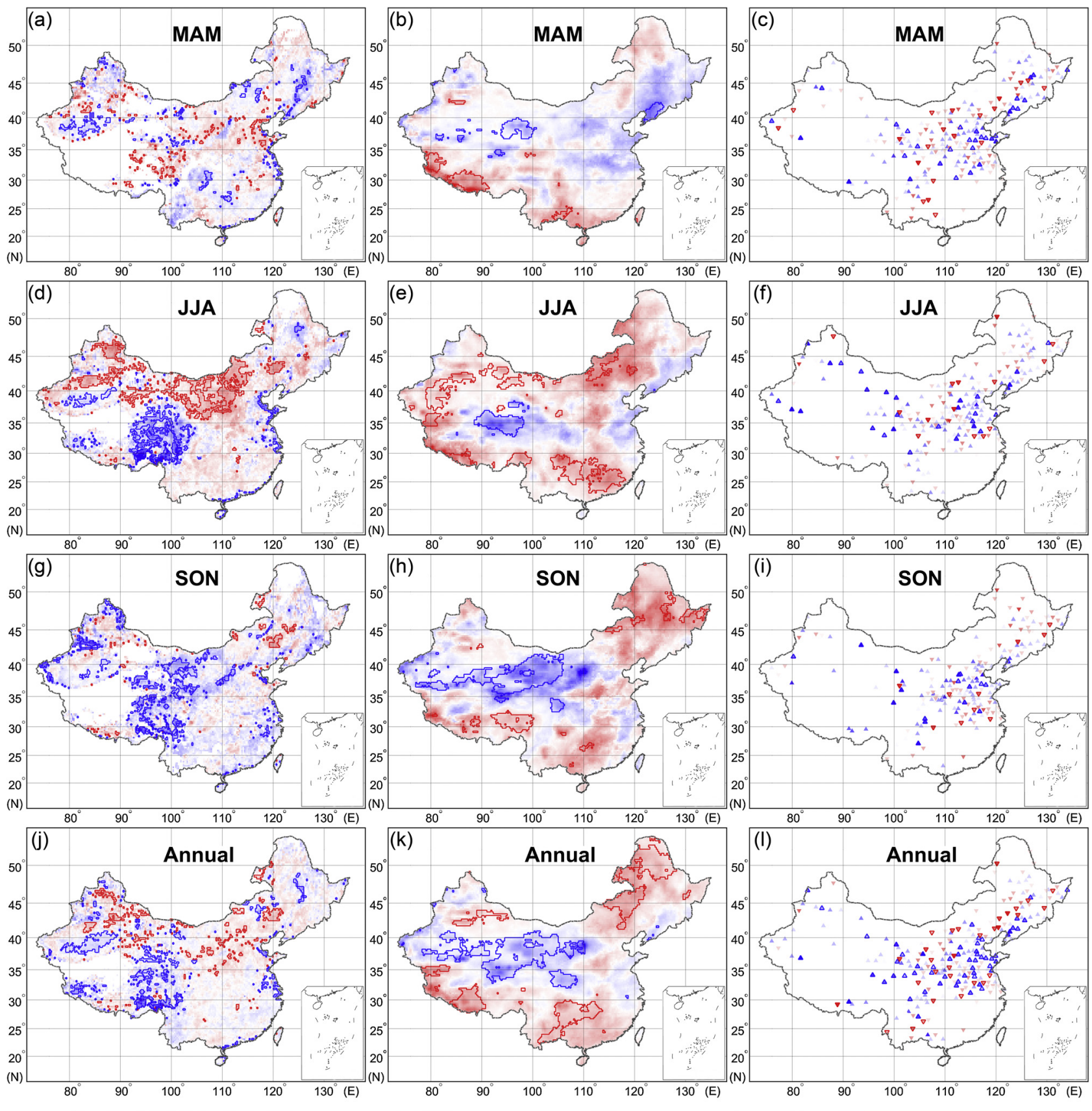

\section{$-0.006$ \\ $-0.004$ \\ $-0.002 \quad 0.000$ \\ 0.002 \\ 0.004 \\ Changes in surface soil moisture $\left(\mathrm{m}^{3} \mathrm{~m}^{-3} \mathrm{yr}^{-1}\right)$}

0.006

0.008

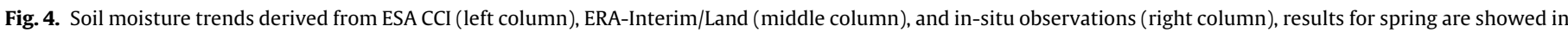

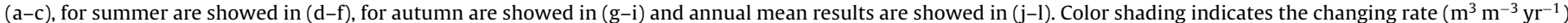

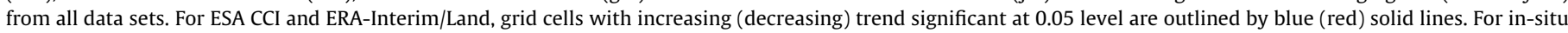

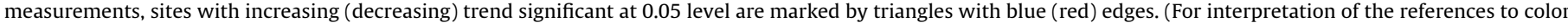
in this figure legend, the reader is referred to the web version of this article.)

It is seen from Fig. 5 that there was no significant trend in precipitation over the Huang-Huai-Hai Plain throughout the year. Although the absolute changing rate of TRMM precipitation during 1998-2010 differed slightly, the spatial patterns of seasonal precipitation trends produced by TRMM (figure not shown) were similar to those of IGSNRR, and further enhanced the confidence in the results of precipitation trend analysis.

\section{Discussions}

\subsection{Reasons underlying the difference between precipitation and soil moisture trends}

Anthropogenic activities, including massive groundwater-fed irrigation are considered to underlie the difference between precipitation and soil moisture trends. It is proved in previous studies 

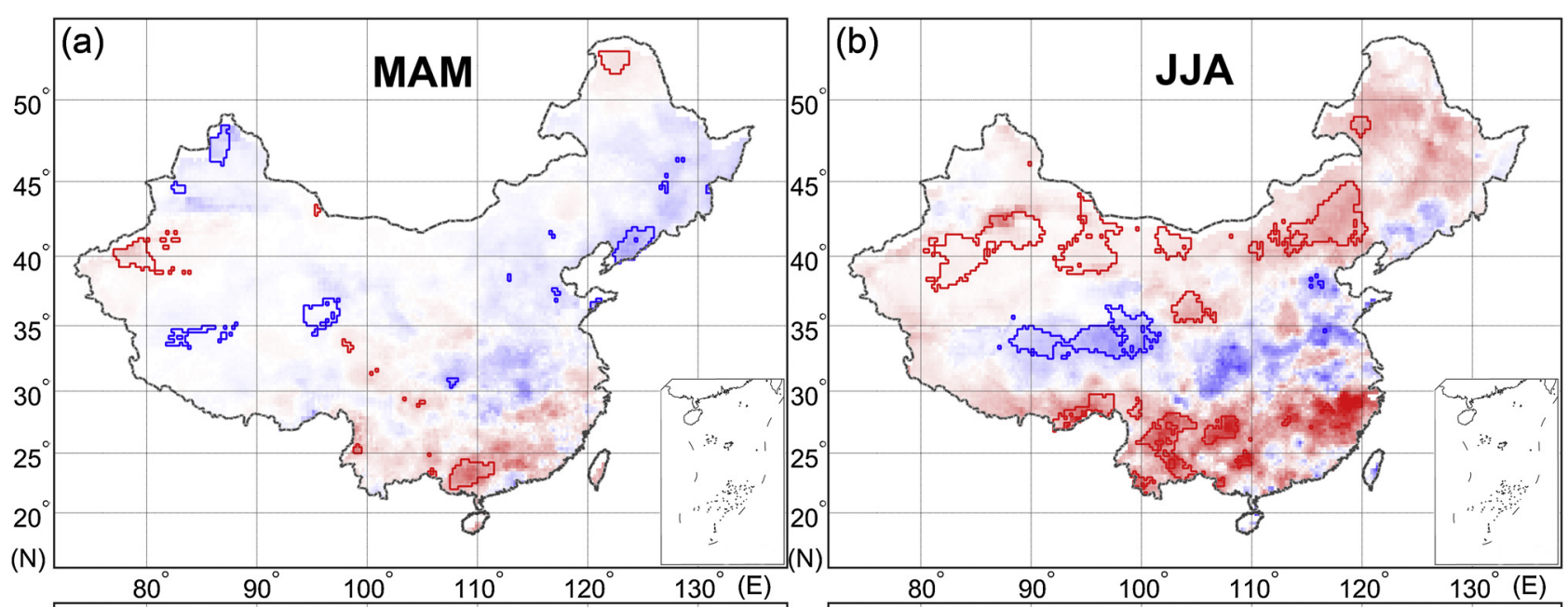
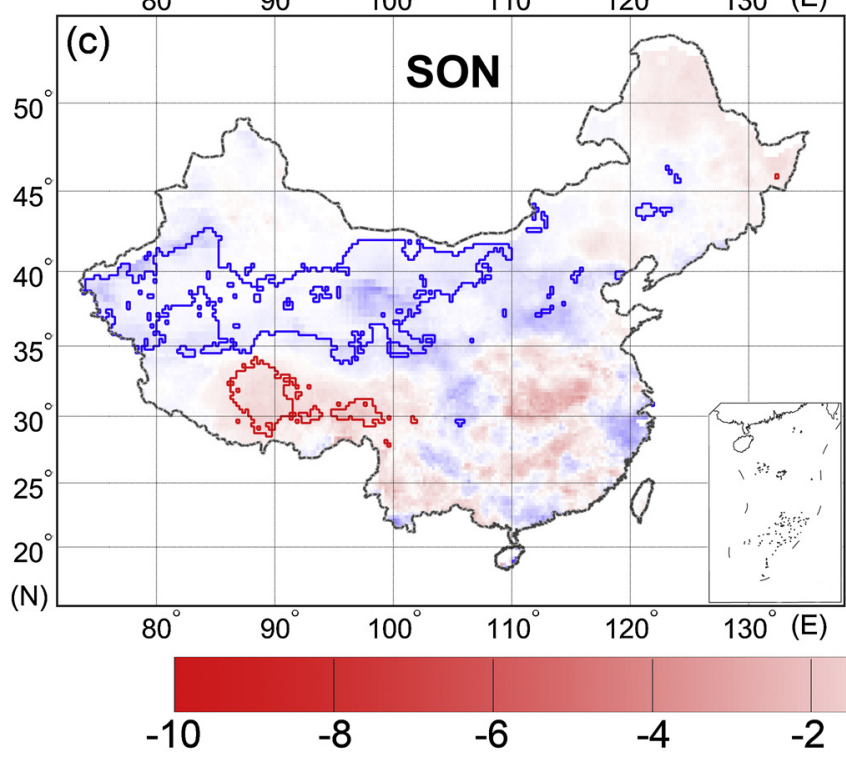

Changes in annual

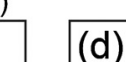

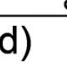
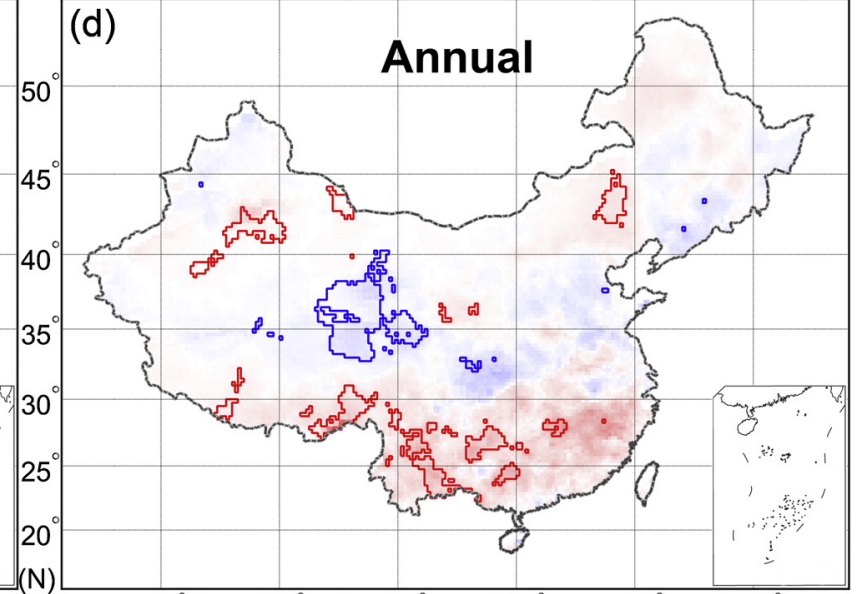

(1)
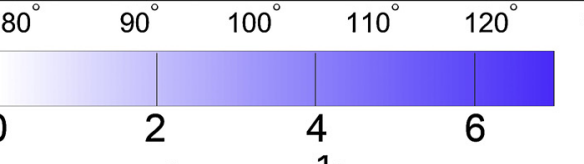

$130^{\circ}(\mathrm{E})$

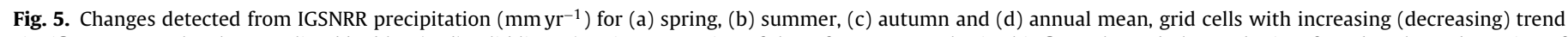

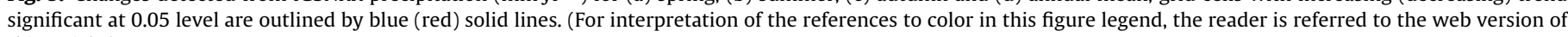
this article.)

that irrigation, as an additional water supply source other than precipitation, has the impact of reducing soil albedo, increasing soil heat capacity, altering local soil moisture content, and affecting the water/energy budget by transforming evapotranspiration regime from water-limited to energy-limited (Shi et al., 2014; Taylor et al., 2012). The Huang-Huai-Hai Plain, regarded as the 'Granary of China', is one of the most intensively irrigated regions in the world (Shi et al., 2014; Siebert et al., 2005). In terms of area equipped for irrigation (AEI), all five provinces in the Huang-Huai-Hai Plain are top ranking provinces in China. Fig. 6a shows the spatial distribution of AEI in China as percentage of total 5 arc-minute grid cell around 2005 (Siebert et al., 2013). During the period of 1995-2007, the Huang-Huai-Hai Plain had experienced population explosion and significant expansion in crop areas and irrigated land according to remote sensing and land-use change interpretations (Liu et al., 2003, 2010). Based on data from National Bureau of Statistics of China (http://www.stats.gov.cn/english/), due to the massive agricultural infrastructure construction projects, there was a steady growth in AEI for provinces in the Huang-Huai-Hai Plain during the same period (Fig. 6b).
Due to insufficient rainfall and decreasing runoff, irrigation in the Huang-Huai-Hai Plain is mainly sourced from groundwater at a speed far exceeding the recharge rate (Hu et al., 2010), which explains the level or slightly decreased time series in the amount of surface water diversion for irrigation (Fig. 6b), and results in the generally higher evapotranspiration than precipitation at the basin scale (Cao et al., 2014). The annual groundwater extraction in Henan, Hebei and Shandong provinces approximated or well exceeded 10 billion $\mathrm{m}^{3}$ during 2004-2009 (http://www.stats.gov. $\mathrm{cn} /$ english/). The significant depletion was also evidenced by various investigations on groundwater resources of this region using the Gravity Recovery and Climate Experiment (GRACE) satellites (Liu et al., 2015; Tang et al., 2013), using groundwater monitoring wells (Wang et al., 2009), and using tracer experiment (Tan et al., 2014). The excessive groundwater extraction is considered as the "external" water sources to local surface soil water, and contributes to the large difference in observed trends between soil moisture and precipitation. In addition, inter-basin water transfer is another factor underlying the difference between precipitation and soil moisture trends. On the basin scale, the transferred water (from exterior basins) accounted for $10.5 \%$ and $13.0 \%$ of 

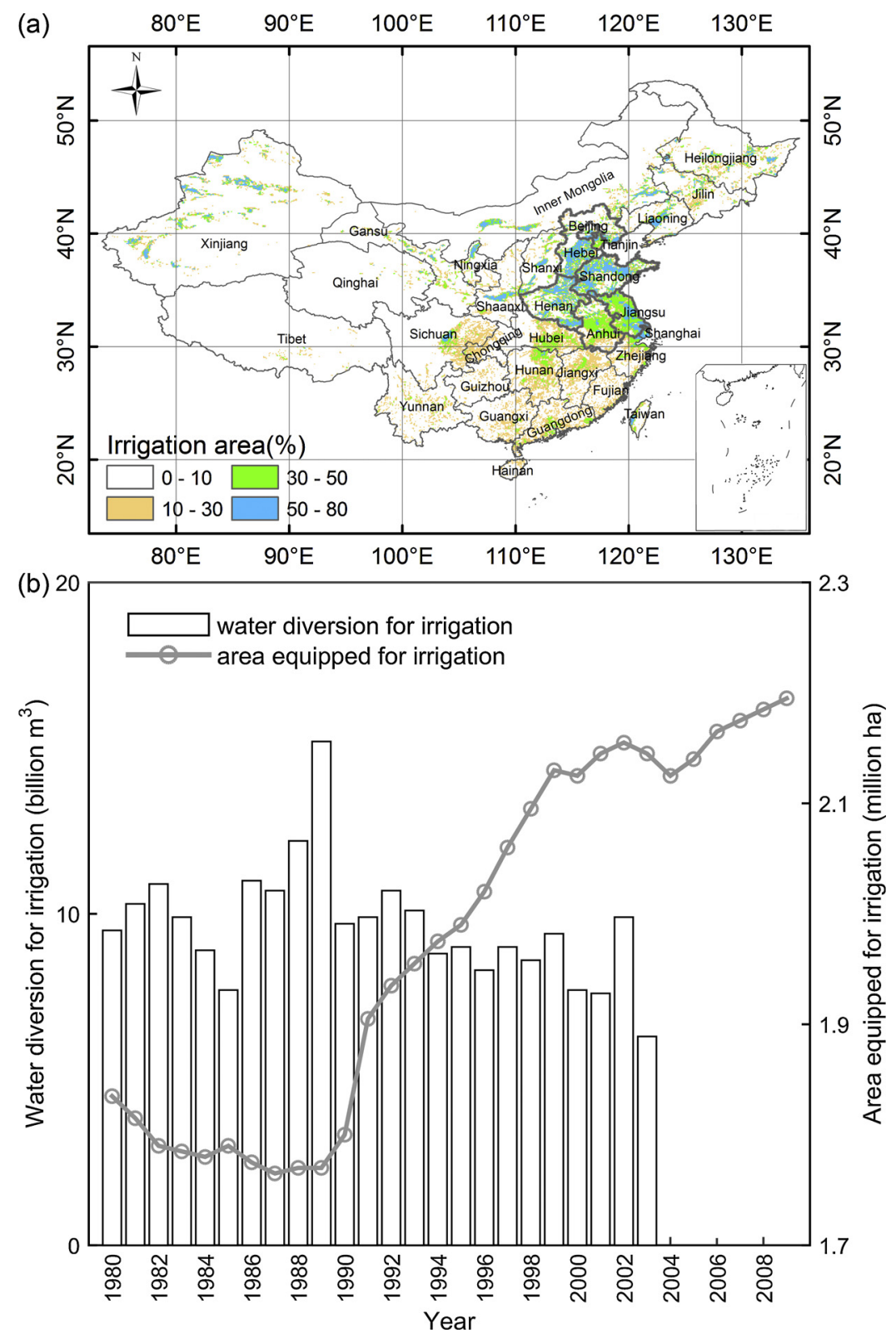

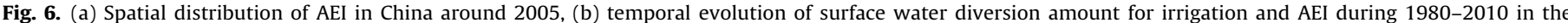
Huang-Huai-Hai Plain.

the total water supply in Hai River basin and Huai River basin respectively, according to the water resources bulletin of these two basins. This large-scale redistribution of water exerts significant one-directional impact on surface soil moisture of receiving basin (Chen and Xie, 2010), and thus contributes to the aforementioned difference in trends derived from soil moisture and precipitation.

With respect to the irrigation time schedule, as precipitation in Huang-Huai-Hai Plain mainly occurs during July to August, agricultural irrigation is often conducted in the early summer (May-June) during the milking stage, i.e., the critical growth stage for winter wheat, and in autumn (late September) before the planting of winter wheat (Wang et al., 2006). Generally, three to four times of irrigations are applied each year in this region to ensure highyielding wheat production (Li et al., 2005; Zhang et al., 2003). This irrigation schedule is considered to contribute to the noticeable difference between remotely sensed ESA CCI soil moisture and other land surface model during summer and autumn.
To further demonstrate the effect of irrigation on soil moisture trend, we examined the trends derived by ESA CCI and ERA-Interim/Land during growing season for areas with different irrigation levels. After re-sampling the 5 arc-minute AEI to $0.25^{\circ}$, we conducted zonal analysis for areas with three AEI levels, i.e., $0-10 \%$, $10-50 \%$ and $50-80 \%$, then assessed the hypothesis that grids with higher irrigation level show higher soil moisture change rate using Student's $t$-test. The medians of change rates for all grids with the same irrigation level during May-September are shown in Fig. 7, and Student's $t$-test results with significant levels of 0.05 and 0.01 are marked with one and two asterisks respectively. To avoid the impact of precipitation change, the grids with significant precipitation trends $(p<0.05)$ were excluded. It is seen that for irrigation scheduling months of May, June and September, the soil moisture change rates from ESA CCI were significantly higher in 10-50\% irrigation level than those in 0-10\% level. On the other hand, ERAInterim/Land only detected the significantly higher change rate in 

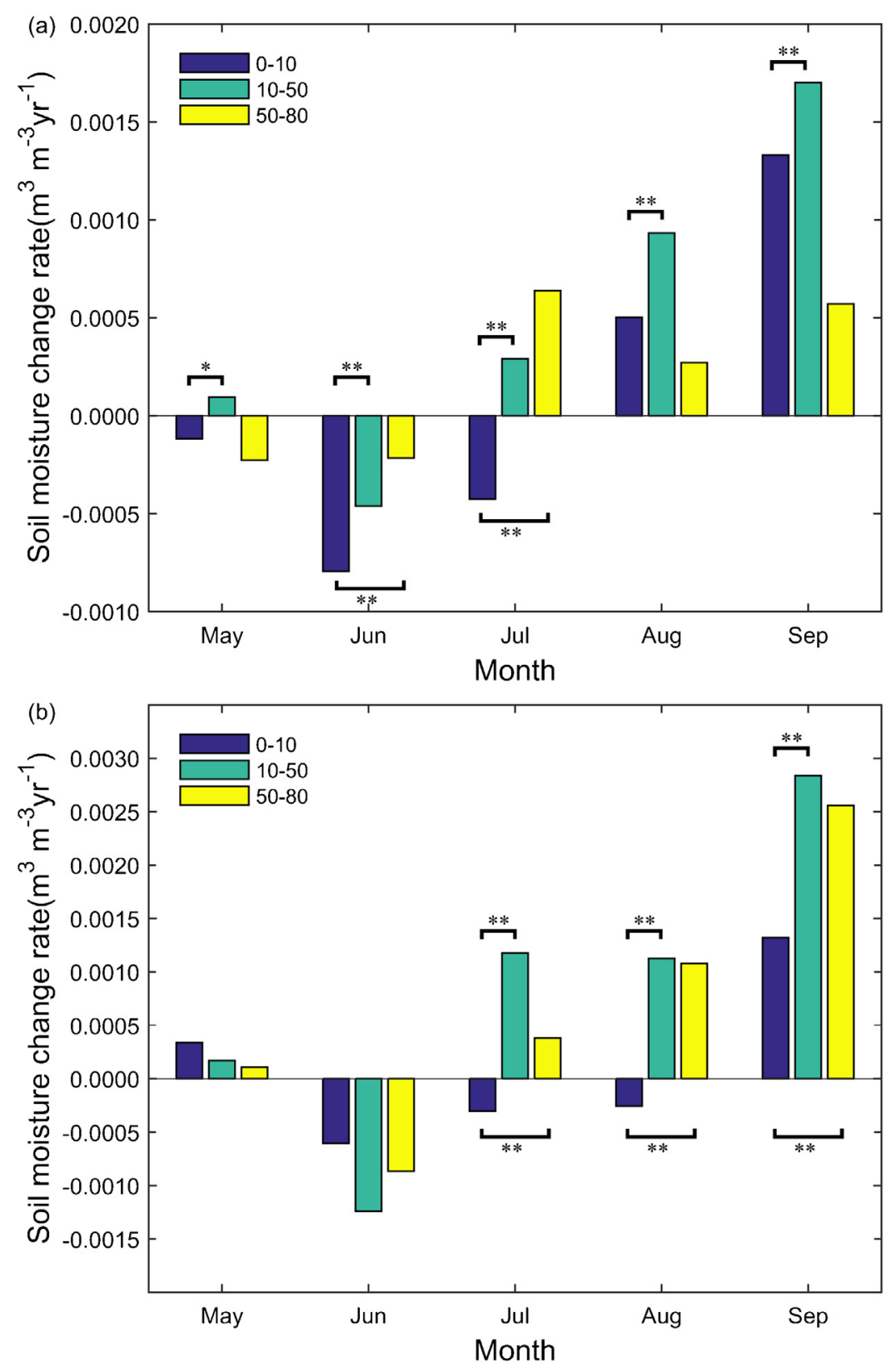

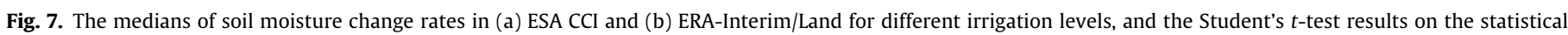
difference in change rates between various irrigation levels (one and two asterisks represent significant levels of 0.05 and 0.01 respectively).

10-50\% level for September, rather than all three irrigation months (May, June and September). It is worthy to note that areas with 50-80\% irrigation level was experiencing land-use change such as urbanization (Shi et al., 2013), and the 10-50\% irrigated areas were confirmed to have the most prominent irrigation cooling effect (Shi et al., 2014). This partly explains the phenomenon of less significant difference in soil moisture change rates between $50-80 \%$ level and $0-10 \%$ level.

\subsection{Implication of the comparison results}

Soil moisture trends in China for the recent fifteen years (1996-2010) derived from in-situ measurements, ESA CCI product and ERA-Interim/Land reanalysis were in general consensus with those using land surface model simulations from previous studies. For instance, in alignment with results of Wang et al. (2011), who employed four physically-based land surface models (VIC, CLM3.5,
Noah2.7, and VIC-CLM3.5 hybrid) to investigate soil moisture trend in China, it is also found that soil moisture in northern China had significant downward trends. However, there is also obvious difference in the resulted trends between Wang's work and this study, especially in the Huang-Huai-Hai Plain. Instead of showing significant drying trend, in-situ measurements, ESA CCI product and ERA-Interim/Land reanalysis (especially the former two data sets) all demonstrated wetting trend for summer and early autumn in this region.

It is expected that soil moisture patterns generated from offline land surface model will resemble those from precipitation data set, as precipitation is the main driver of variations in soil moisture. Therefore, it is not surprising that long-term soil moisture trend largely reflects the trend derived from precipitation (Albergel et al., 2013b; Wang et al., 2011). However, it is seen from this study that in irrigated areas, especially in the Huang-Huai-Hai Plain, the analyzed trends using in-situ and remotely sensed soil moisture 
observations noticeably deviated from those using land surface model simulation and precipitation. Although ERA-Interim/Land was built on extensive assimilation of meteorological observations (Balsamo et al., 2015), it does not take into account the human alteration on the quantity and distribution of water in the terrestrial system, which partly contributes to the observed discrepancy between ERA-Interim/Land reanalysis and ESA CCI. This indicates that regional surface water change exerted by anthropogenic activities cannot be neglected. Therefore, for soil moisture modeling in this region, modules accounting for irrigation practice is crucial in depicting the trend and dynamics of soil moisture. In addition, when assimilating microwave soil moisture into the hydrological model, water balance scheme should be adjusted with caution, as the external source of water account for $10-20 \%$ of total water supply in this region.

In addition, the time frame should be taken into account when interpreting the results of this study, as the length of time series will affect trend analysis result (Miralles et al., 2014). To fairly compare the trend analysis results from remotely sensed, reanalysis and in-situ soil moisture, the study period of this paper was selected as 1996-2010 so that all three soil moisture data sets have the minimum data gaps. Under this 15 -year time frame, we observed difference in the trends between soil moisture and precipitation for summer and autumn in the Huang-Huai-Hai Plain, which is largely contributed to the massive anthropogenic interference, including the expansion of crop area and the AEI, as well as the excessive groundwater extraction. It is noted that the majority of massive agricultural infrastructure construction projects were conducted since the 1990s, as can be seen from the rapid increase in AEI time series after 1995 (Fig. 6b) and the rapid expansion of total crop area ever since (Liu et al., 2015). Prior to this period, soil moisture was more explicitly controlled by climate variability, which partly explains the difference in trend analysis results of this study and those using land surface model at longer time frame.

\section{Summary and conclusion}

In this study, we investigated the long-term soil moisture trends over China using three soil moisture data sets, namely microwavebased multi-satellite surface soil moisture product (ESA CCI), ERAInterim/Land reanalysis, and in-situ measurements collected from nationwide agro-meteorological network.

A detailed comparative study was conducted on the performance of three data sets in evaluating temporal trend of soil moisture. It is found that for annual mean time series, around $30 \%$ (34-39\%) of in-situ sites with significant increasing (decreasing) soil moisture trend were collocated with ESA CCI grids that showed the same level of significant increase (decrease) (Table 1). The consistency with in-situ measurements was relatively lower for ERA-Interim/Land reanalysis, as $24 \%$ (19-23\%) of sites with significant increasing (decreasing) trend were identified to be significantly wetting (drying) by ERA-Interim/Land. From the gridbased intercomparison between ESA CCI and ERA-Interim/Land, it is seen that taking ESA CCI as benchmark, considerable percentage of area (40\%) with significantly increasing trend were identified as decreasing by ERA Interim/Land (Fig. 3).

Spatial patterns of consistency in detected trends between precipitation and three soil moisture data sets were also examined. Results showed that both ESA CCI and ERA-Interim/Land demonstrated general decreasing trend in north Inner Mongolia and northwest China during summer, which was in agreement with IGSNRR precipitation (Figs. 4 and 5). However, discrepancies between precipitation and soil moisture data sets were also observed, especially in major irrigation regions of China. It is noted that in close resemblance to IGSNRR, ERA-Interim/Land detected a significant decreasing trend in Sichuan province of southwest China, while a contrasting trend was derived from ESA CCI for spring with no significant change for the rest seasons. Moreover, it is seen that ESA CCI detected a significant wetting trend in oases to the north rim of the Tarim Basin during autumn when irrigation took place, whereas the trend was much less obvious in ERA-Interim/Land.

Discrepancy between soil moisture and precipitation exhibited in the most intensively cropped Huang-Huai-Hai Plain was prominent. Massive anthropogenic interference on the local water resources, including groundwater-fed irrigation is considered to be the underlying cause for this discrepancy. This is confirmed by the spatial collocation of significantly wetting areas and heavily irrigated areas, as well as the grid-based Student's $t$-test taking samples from various irrigation levels (Fig. 7). As the area equipped for irrigation (AEI) had gone through steady growth since the 1990s (Fig. 6), and most of the agricultural water use in this region was continuously sourced from groundwater and exterior basins, surface soil moisture in the Huang-Huai-Hai Plain showed a significant increasing trend for summer even though precipitation did not change significantly during the study period. Results indicate that, for soil moisture modeling in regions with great magnitude of human interference, modules considering actual irrigation practice are crucial for successfully capturing long-term trend. Furthermore, massive water transfer should be considered to avoid water imbalance when assimilating microwave-based soil moisture at regional scale.

\section{Acknowledgment}

This work was supported by National Natural Science Foundation of China (Grant Nos. 41501450, 41071054, 41501415) and the Basic Research and Operating Expenses of CAMS (Grant No. 2013Y006). The authors would like to thank the reviewers and the editors for their constructive comments and suggestions on the earlier draft of the paper.

\section{References}

Adler, R., Huffman, G., Chang, A., Ferraro, R., Xie, P., Janowiak, J., Rudolf, B., Schneider, U., Curtis, S., Bolvin, D., Gruber, A., Susskind, J., Arkin, P., Nelkin, E., 2003. The version 2 global precipitation climatology project (GPCP) monthly precipitation analysis (1979-present). J. Hydrometeorol. 4 (6), 1147-1167.

Ahmad, S., Kalra, A., Stephen, H., 2010. Estimating soil moisture using remote sensing data: a machine learning approach. Adv. Water Resour. 33 (1), 69-80.

Albergel, C., Dorigo, W., Balsamo, G., Muñoz-Sabater, J., de Rosnay, P., Isaksen, L., Brocca, L., de Jeu, R., Wagner, W., 2013a. Monitoring multi-decadal satellite earth observation of soil moisture products through land surface reanalyses. Remote Sens. Environ. 138 (6), 77-89.

Albergel, C., Dorigo, W., Reichle, R., Balsamo, G., Rosnay, P., Muñoz-Sabater, J., Isaksen, L., de Jeu, R., Wagner, W., 2013b. Skill and global trend analysis of soil moisture from reanalyses and microwave remote sensing. J. Hydrometeorol. 14 (4), 1259-1277.

Balsamo, G., Albergel, C., Beljaars, A., Boussetta, S., Brun, E., Cloke, H., Dee, D., Dutra, E., Muñoz-Sabater, J., Pappenberger, F., de, R., osnay, P., Stockdale, T., Vitart, F., 2015. ERA-Interim/Land: a global land surface reanalysis data set. Hydrol. Earth Syst. Sci. 19 (1), 389-407.

Cao, G., Han, D., Song, X., 2014. Evaluating actual evapotranspiration and impacts of groundwater storage change in the North China Plain. Hydrol. Process. 28 (4), 1797-1808

Chen, F., Xie, Z., 2010. Effects of interbasin water transfer on regional climate: a case study of the middle route of the South-to-North water transfer project in China. J. Geophys. Res.: Atmos. 115 (D11), D11112.

Dahmen, E., Hall, M., 1990. Screening of Hydrological Data: Tests for Stationarity and Relative Consistency. International Institute for Land Reclamation and Improvement (ILRI), pp. 49-58.

Dorigo, W., Gruber, A., de, J., eu, R., Wagner, W., Stacke, T., Loew, A., Albergel, C., Brocca, L., Chung, D., Parinussa, R., Kidd, R., 2015. Evaluation of the ESA CCI soil moisture product using ground-based observations. Remote Sens. Environ. $162,380-395$

Dorigo, W., de Jeu, R., Chung, D., Parinussa, R., Liu, Y., Wagner, W., Fernández-Prieto D., 2012. Evaluating global trends (1988-2010) in harmonized multi-satellite surface soil moisture. Geophys. Res. Lett. 39 (18), 143-157. 
Drewniak, B., Song, J., Prell, J., Kotamarthi, V., Jacob, R., 2013. Modeling agriculture in the community land model. Geosci. Model Dev. 6 (2), 495-515.

GCOS Secretariat, 2010. Implementation plan for the Global Observing System for Climate in support of the UNFCCC (2010 Update). World Meteorological Organization, Geneva Switzerland.

Green, T., Erskine, R., 2004. Measurement, scaling, and topographic analyses of spatial crop yield and soil water content. Hydrol. Process. 18 (8), 1447-1465.

Hain, C., Crow, W., Mecikalski, J., Anderson, M., Holmes, T., 2011. An intercomparison of available soil moisture estimates from thermal infrared and passive microwave remote sensing and land surface modeling. J. Geophys. Res. 116 (D15), 1158-1162.

Hirsch, R., Slack, J., Smith, R., 1982. Techniques of trend analysis for monthly water-quality data. Water Resour. Res. 18 (1), 107-121.

Hirschi, M., Mueller, B., Dorigo, W., Seneviratne, S.I., 2014. Using remotely sensed soil moisture for land-atmosphere coupling diagnostics: the role of surface vs. root-zone soil moisture variability. Remote Sens. Environ. 154, 246-252.

Hu, S., Mo, X., Lin, Z., Qiu, J., 2010. Emerge assessment of a wheat-maize rotation system with different water assignments in the North China Plain. Environ. Manage. 46 (4), 643-657.

Huffman, G., Adler, R., Arkin, P., Chang, A., Ferraro, R., Gruber, A., Janowiak, J., McNab, A., Rudolph, B., Schneider, U., 1997. The global precipitation climatology project (GPCP) combined precipitation data set. Bull. Am. Meteorol. Soc. 78 (1), 5-20.

Huffman, G., Adler, R., Bolvin, D., Gu, G., Nelkin, E., Bowman, K., Hong, Y., Stocker, E., 2007. The TRMM Multi-satellite Precipitation Analysis (TMPA): quasi-global, multiyear, combined-sensor precipitation estimates at fine scales. J. Hydrometeorol. 8 (1), 38-55

Huffman, G., Adler, R., Bolvin, D., Nelkin, E., 2010. The TRMM multi-satellite precipitation analysis (TMPA). In: Satellite Rainfall Applications for Surface Hydrology. Springer, Netherlands, pp. 3-22

Jaynes, D., Kaspar, T., Colvin, T., James, D., 2003. Cluster analysis of spatiotemporal corn yield patterns in an Iowa field. Agron. J. 95 (3), 574-586.

Kendall, M., 1975. Rank Correlation Methods. Charles Griffin \& Co. Ltd., pp. pp202

Khaliq, M., Ouarda, T., Gachon, P., Sushama, L., St-Hilaire, A., 2009. Identification of hydrological trends in the presence of serial and cross correlations: a review of selected methods and their application to annual flow regimes of Canadian rivers. J. Hydrol. 368 (1-4), 117-130.

Li, J., Inanaga, S., Li, Z., Eneji, A., 2005. Optimizing irrigation scheduling for winter wheat in the North China Plain. Agric. Water Manage. 76 (1), 8-23.

Liu, J., Liu, M., Zhuang, D., Zhang, Z., Deng, X., 2003. Study on spatial pattern of land-use change in China during 1995-2000. Sci. China Series D: Earth Sci. 46 (4), 373-384

Liu, J., Zhang, Z., Xu, X., Kuang, W., Zhou, W., Zhang, S., Li, R., Yan, C., Yu, D., Wu, S., 2010. Spatial patterns and driving forces of land use change in China during the early 21st century. J. Geogr. Sci. 20 (4), 483-494.

Liu, Y., Dorigo, W., Parinussa, R., de Jeu, R., Wagner, W., McCabe, M., Evans, J., Dijk, A., 2012. Trend-preserving blending of passive and active microwave soil moisture retrievals. Remote Sens. Environ. 123 (3), 280-297.

Liu, Y., Pan, Z., Zhuang, Q., Miralles, D., Teuling, A., Zhang, T., An, P., Dong, Z., Zhang J., He, D., Wang, L., Pan, X., Bai, W., Niyogi, D., 2015. Agriculture intensifies soil moisture decline in Northern China. Sci. Rep. 5, 11261

Liu, Y., Parinussa, R., Dorigo, W., de Jeu, R., Wagner, W., van Dijk, A., McCabe, M. Evans, J., 2011. Developing an improved soil moisture dataset by blending passive and active microwave satellite-based retrievals. Hydrol. Earth Syst. Sci. 15 (2), 425-436.

Loew, A., Stacke, T., Dorigo, W., de Jeu, R., Hagemann, S., 2013. Potential and limitations of multidecadal satellite soil moisture observations for selected climate model evaluation studies. Hydrol. Earth Syst. Sci. 17 (9), 3523-3542.

Ma, Z., Fu, C., 2006. Some evidence of drying trend over northern China from 195 to 2004. Chin. Sci. Bull. 51 (23), 2913-2925.

Mann, H., 1945. Non-parametric test against trend. Econometrica 13 (3), 245-259.

Maurer, E., Wood, A., Adam, J., Lettenmaier, D., Nijssen, B., 2002. A long-term hydrologically based dataset of land surface fluxes and states for the conterminous United States. J. Clim. 15 (22), 3237-3251.

Miralles, D., van den Berg, M., Gash, J., Parinussa, R., de Jeu, R., Beck, H., Holmes, T. Jiménez, C., Verhoest, N., Dorigo, W., Teuling, A., Dolman, A., 2014. El Niéo-La Niéa cycle and recent trends in continental evaporation. Nat. Clim. Change 4 (2), 122-126.

Qiu, J., Mo, X., Liu, S., Lin, Z., Yang, L., Song, X., Zhang, G., Naeimi, V., Wagner, W. 2013. Intercomparison of microwave remote sensing soil moisture datasets based on distributed eco-hydrological model simulation and in-situ measurements over the North China Plain. Int. J. Remote Sens. 34 (19), 6587-6610.

Renard, B., Lang, M., Bois, P., Dupeyrat, A., Mestre, O., Niel, H., Sauquet, E. Prudhomme, C., Parey, S., Paquet, E., Neppel, L., Gailhard, J., 2008. Regional methods for trend detection: assessing field significance and regional consistency. Water Resour. Res. 44 (8), W08419.

Sen, P., 1968. Estimates of the regression coefficient based on Kendall's Tau. J. Am. Stat. Assoc. 63 (324), 1379-1389.

Shepard, D., 1984. Computer mapping: The SYMAP interpolation algorithm. In: Spatial Statistics and Models. Springer, Netherlands, pp. 133-145.

Shi, W., Tao, F., Liu, J., 2013. Changes in quantity and quality of cropland and the implications for grain production in the Huang-Huai-Hai Plain of China. Food Secur. 5 (1), 69-82.

Shi, W., Tao, F., Liu, J., 2014. Regional temperature change over the Huang-Huai-Hai Plain: the roles of irrigation versus urbanization. Int. J. Climatol. 34 (4), 1181-1195

Siebert, S., Döll, P., Hoogeveen, J., Faures, J., Frenken, K., Feick, S., 2005. Development and validation of the global map of irrigation areas. Hydrol. Earth Syst. Sci. 9 (5), 535-547.

Siebert, S., Henrich, V., Frenken, K., Burke, J., 2013. Global map of irrigation areas, version 5. Food and Agriculture Organization of the United Nations, Rome, available at http://www.fao.org/nr/water/aquastat/irrigationmap/index10.stm.

Su, B., Wang, A., Wang, G., Wang, Y., Jiang, T., 2016. Spatiotemporal variations of soil moisture in the Tarim River basin, China. Int. J. Appl. Earth Observ. Geoinform. 48, 122-130

Tan, X., Wu, J., Cai, S., Yang, J., 2014. Characteristics of groundwater recharge on the North China Plain. Groundwater 52 (5), 798-807.

Tang, Q., Wood, A., Lettenmaier, D., 2009. Real-time precipitation estimation based on index station percentiles. J. Hydrometeorol. 10 (1), 266-277.

Tang, Q., Zhang, X., Tang, Y., 2013. Anthropogenic impacts on mass change in North China. Geophy. Res. Lett. 40 (15), 3924-3928.

Taylor, R., Scanlon, B., Döll, P., Rodell, M., van Beek, R., Wada, Y., Longuevergne, L. Leblanc, M., Famiglietti, J., Edmunds, M., 2012. Ground water and climate change. Nat. Clim. Change 3 (4), 322-329.

Wagner, W., Dorigo, W., de Jeu, R., Fernandez, D., Benveniste, J., Haas, E., Ertl, M., 2012. Fusion of active and passive microwave observations to create an essential climate variable data record on soil moisture. ISPRS Ann. Photogramm. Remote Sens. Spat. Inform. Sci. I-7, 315-321.

Wang, A., Lettenmaier, D., Sheffield, J., 2011. Soil moisture drought in China, 1950-2006. J. Clim. 24 (13), 3257-3271.

Wang, H., Yang, Z., Saito, Y., Liu, J., Sun, X., 2006. Interannual and seasonal variation of the Huanghe (Yellow River) water discharge over the past 50 years: connections to impacts from ENSO events and dams. Glob. Planet. Change 50 (3), 212-225.

Wang, S., Song, X., Wang, Q., Xiao, G., Liu, C., Liu, J., 2009. Shallow groundwater dynamics in North China Plain. J. Geogr. Sci. 19 (2), 175-188.

Wang, Z., Zhai, P., Zhang, H., 2003. Variation of drought over northern China during 1950-2000. J. Geogr. Sci. 13 (4), 480-487.

Wei, L., Zhang, B., Wang, M., 2007. Effects of antecedent soil moisture on runoff and soil erosion in alley cropping systems. Agric. Water Manage. 94 (1-3), 54-62.

Xin, X., Yu, R., Zhou, T., Wang, B., 2006. Drought in late spring of south China in recent decades. J. Clim. 19 (13), 3197-3206.

Yuan, X., Ma, Z., Pan, M., Shi, C., 2015. Microwave remote sensing of short-term droughts during crop growing seasons. Geophys. Res. Lett. 42 (11), 4394-4401

Zhai, J., Su, B., Valentina, K., Tobias, V., Gao, C., Jiang T., 2010. Spatial variation and trends in PDSI and SPI indices and their relation to streamflow in 10 large regions of China. J. Clim. 23 (3), 649-663.

Zhang, X., Pei, D., Hu, C., 2003. Conserving groundwater for irrigation in the North China Plain. Irrig. Sci. 21 (4), 159-166.

Zhang, X., Tang, Q., Pan, M., Tang, Y., 2014. A long-term land surface hydrologic fluxes and states dataset for China. J. Hydrometeorol. 15 (5), 2067-2084.

Zou, J., Xie, Z., Yu, Y., Zhan, C., Sun, Q., 2014. Climatic responses to anthropogenic groundwater exploitation: a case study of the Haihe River Basin, Northern China. Clim. Dyn. 42 (7-8), 2125-2145

Zou, X., Zhai, P., Zhang, Q., 2005. Variations in droughts over China: 1951-2003. Geophys. Res. Lett. 32 (4), L04707.

Zuo, Z., Zhang, R., 2007. The spring soil moisture and the summer rainfall in eastern China. Chin. Sci. Bull. 52 (23), 3310-3312. 